\title{
UMA LEITURA ONTOMETODOLÓGICA DA EDUCAÇÃO AMBIENTAL CRÍTICA DIANTE DOS DESAFIOS SOCIETÁRIOS CONTEMPORÂNEOS
}

\author{
César Augusto Costa ${ }^{1}$ \\ Carlos Frederico Bernardo Loureiro ${ }^{2}$
}

Resumo: O objetivo deste texto, ao considerarmos o cenário de crise ambiental e civilizatória, é situar a relevância na discussão ambiental da unidade dialética entre sociedade-natureza à luz do referencial materialista histórico-dialético centrado na ontologia do ser social. Compreendemos ser necessário contextualizarmos as transformações que o cenário contemporâneo suscita à educação ambiental crítica. Tal panorama aponta para o crucial debate sobre a sustentabilidade e sobre qual sustentabilidade, fruto de um projeto colonizador europeu fundado na proposta de mercantilização da natureza e, por sua vez, do ser humano. Após fazer estas considerações teóricas e contextuais iniciais, explicitaremos os pressupostos da Educação Ambiental Crítica à luz da ontologia marxiana ambiental, o qual tem em seu horizonte, a finalidade de emancipar o homem visando superar a dissociação sociedade-natureza inerente às relações de expropriação e dominação no marco da sociedade capitalista. Feito este exame, assinalamos a contribuição teórico-metodológica do conceito de práxis e sua pertinência na educação ambiental que defendemos.

Palavras-chave: Educação Ambiental Crítica; Materialismo Histórico-Dialético; Práxis; Sociedade-Natureza; Sustentabilidade.

${ }^{1}$ Doutorando em Educação Ambiental/FURG. Bolsista do CNPq/Brasil, Pesquisador do Laboratório de Investigações em Educação, Ambiente e Sociedade (LIEAS/UFRJ). E-mail: csc193@hotmail.com.

${ }_{2}$ Doutor em Serviço Social/UFRJ. Bolsista de Produtividade do CNPq/Brasil, Líder do Laboratório de Investigações em Educação, Ambiente e Sociedade (LIEAS/UFRJ). Professor do PPGE da UFRJ, do PPG em Ecologia Social da UFRJ e do PPGEA/FURG. E-mail: floureiro@openlink.com.br.

Revbea, São Paulo, V. 9, N 1:132-156, 2014. 


\section{Introdução}

A intenção primeira deste artigo, ao considerarmos o cenário de crise ambiental e civilizatória, é situar a relevância na discussão ambiental da unidade dialética entre sociedade-natureza (FOSTER, 2005; LOWY, 2005; COGGIOLA, 1997; NETTO E BRÁZ, 2010; FOLADORI,1997) à luz do referencial materialista histórico-dialético centrado na ontologia do ser social. Compreendemos ser necessário contextualizarmos as transformações que o cenário contemporâneo suscita à educação ambiental crítica. Tal panorama aponta para o crucial debate sobre a sustentabilidade e sobre qual sustentabilidade, fruto de um projeto colonizador europeu fundado na proposta de mercantilização da natureza e, por sua vez, do ser humano (PORTOGONÇALVES, 2002).

Após fazer estas considerações teóricas e contextuais iniciais, explicitaremos os pressupostos da Educação Ambiental Crítica à luz da ontologia marxiana ambiental, o qual tem em seu horizonte, a finalidade de emancipar o homem visando superar a dissociação sociedade-natureza inerente às relações de expropriação e dominação no marco da sociedade capitalista (HARVEY, 1996; ALTVATER, 2006). Feito este exame, assinalamos a contribuição teórico-metodológica do conceito de práxis (GADOTTI, 1983; SANCHEZ GAMBOA, 1989; FRIGOTTO, 1989; SANFELICE, 2005; PALÁZON MAYORAL, 2007) e sua pertinência na educação ambiental que defendemos (LOUREIRO, 2004; 2007b).

\section{A Premissa: O debate Ambiental em Karl Marx}

Para o pensamento marxista, a relação e as origens do agravamento da crise ambiental atual estão alicerçadas nas contradições sociais do modo de produção capitalista (FOLADORI, 1997; LOWY, 2005; FOSTER, 1999, 2005; MÉSZÁROS, 2006) o qual destacamos o trabalho como central para o entendimento das relações apontadas (NETTO; BRAZ, 2010; COSTA, VÉRASNETO, LOUREIRO, 2011).

Reiteramos que a relação do homem com a natureza não é uma relação de mão única. Trata-se de uma determinação recíproca, pois subjetivar as forças da natureza e, objetivar-se como ser humano são dois momentos de um mesmo processo unitário. Ou melhor, apropriar-se da natureza nada tem a ver - no sentido ontológico - com tomar posse dela sob a forma mercantil. Marx pontua uma humanização da natureza e uma naturalização do homem, ou seja, um intercâmbio em que a natureza é transformada no "corpo inorgânico do homem". Do ponto de vista crítico, questionamos as razões para que esta relação com a natureza se realize de forma mercantil, que desumaniza a natureza, como o próprio homem. Tal relação não é da natureza ontológica do processo social, mas indica uma forma histórica marcada pela alienação (TONET, 2013).

Logo, uma relação pautada no uso intensivo da natureza, sua redução à condição de recursos econômico-mercantis, se vincula ao conjunto das

revista brasileira educação ambiental 
relações sociais estruturais do capitalismo, ou seja, ao metabolismo sociedadenatureza fundado na apropriação privada dos meios de produção e na acumulação de riqueza material socialmente produzida. Nestes termos, o debate ambiental no âmbito do marxismo exige o reconhecimento da centralidade de categorias como práxis, trabalho, totalidade e da ontologia do ser social (LUKÁCS, 1979; CHASIN, 1995; TONET, 2013)

\section{A concepção de natureza e trabalho em Marx}

A sociedade não é simplesmente um agregado de homens e mulheres, nem muito menos uma soma de ambos. Não podemos separar a sociedade de seus membros, uma vez que, não existe sociedade sem que estejam em interação os seus membros, assim como não existe seres sociais (homens e mulheres) isolados e fora das relações que constitui a sociedade (NETTO; BRAZ, 2010). O que denominamos sociedade são as maneiras de existir do ser social. É na/pela sociedade e nos seus membros que a compõem que o ser social existe, ou seja, a sociedade e seus membros constituem o ser social e dele se constitui. Assim, a sociedade não pode existir sem a natureza, pois ela é a natureza transformada pelo trabalho que propicia as condições de manter a vida dos seus membros, onde nela opera elementos naturais para deles se servir, bem como os meios empregados nesta transformação.

Para chegarmos a uma definição de trabalho, é preciso procurar os elementos que definem ao longo da trajetória humana, bem como as relações estabelecidas entre o homem e o ambiente. Ora, "o trabalho só começa quando uma determinada atividade altera os materiais naturais, modificando sua forma original' (COGGIOLA, 2002, p.182). Ou seja, pode-se definir o trabalho como o processo que realiza a mediação entre sociedade e natureza, quando este põe em ação as forças de que seu corpo está dotado, transformando os elementos que encontra disponíveis na natureza em produtos, suprindo assim suas necessidades, não importando "se elas se originam do estômago ou da fantasia" (MARX, 1985, p.45).

O desenvolvimento do ser social pode ser descrito como o processo de humanização dos homens, através dos quais as determinações naturais sem deixar de existir, desempenham um papel cada vez menor na vida humana. $O$ que queremos apontar é que na medida em que foi se estruturando ao longo do tempo, o trabalho rompe com a ordem natural. Netto e Braz (2010, p.30-31) mencionam que:

Em primeiro lugar, porque o trabalho não se opera com uma atuação imediata sobre a matéria natural; diferentemente, ele exige instrumentos que, no seu desenvolvimento, vão cada vez mais se interpondo entre aqueles que o executam e a matéria; em segundo lugar, porque o trabalho não se realiza cumprindo determinações genéticas, bem ao contrário, passa a exigir habilidades e conhecimentos que se adquirem inicialmente por repetição e experimentação e que se transmitem mediante 
aprendizado. Em terceiro lugar, porque o trabalho não atende a um elenco limitado e praticamente invariável de necessidades, nem as satisfaz sob formas fixas; se é verdade que há um conjunto de necessidades que sempre deve ser atendido (alimentação, proteção contra intempéries, reprodução biológica etc.), as formas desse atendimento variam muitíssimo e, sobretudo, implicam o desenvolvimento, quase sem limites, de novas necessidades.

Tal argumentação acima reafirma que:

o gênero humano resulta de um salto na dinâmica da natureza (orgânica e inorgânica), que sofreu uma inflexão substantivoestrutural quando se instaurou o ser social: este foi colocado pelo processo do trabalho. [...] Com o trabalho, que é uma atividade desconhecida no nível da natureza, posto que especificado pela teleologia (quando o que a natureza conhece é a causalidade), um determinado gênero de ser vivo destacouse da legalidade natural e desenvolveu-se segundo legalidades peculiares. É o pôr teleológico do trabalho que instaura o ser social, cuja existência e desenvolvimento supõem a natureza e o incessante intercâmbio com ela - mas cuja estrutura é diversa dela e dela tende a afastar-se progressivamente, mercê de uma crescente e cada vez mais autônoma complexidade. Portador do ser social, mediante a apropriação da herança cultural pela via da sociabilização, cada indivíduo do gênero humano é tanto singularidade quanto universalidade e só existe como ser social enquanto é ser objetivo - isto é, que se objetiva. E sua objetivação ontológico primária é precisamente o trabalho, atividade necessariamente coletiva - donde a determinação marxiana do homem como ser prático e social (NETTO, 1993, p.35).

Todavia, entendemos no corpo do pensamento marxista que o trabalho humano media a relação sociedade-natureza, tornando adaptada a natureza as demandas humanas, não obstante, a fonte de riqueza é a natureza da qual são os produtos e bens de consumo por via do trabalho (RODRIGUES, 2002). Torna-se evidente nesta abordagem, que para Marx, humanidade e natureza formam uma unidade dialética, onde a humanidade é parte da natureza e se distingue desta ao se constituir socialmente e que a maneira historicamente específica das relações de produção constitui o cerne dessa inter-relação em qualquer período. Pois o mesmo, já havia aludido nos Manuscritos de 1844, citados por Foster e Lowy tal relação: 
O homem vive da natureza, isto é, a natureza é seu corpo, e tem que manter com ela um diálogo ininterrupto se não quiser morrer. Dizer que a vida física e mental do homem está ligada à natureza significa simplesmente que a natureza está ligada a si mesma, porque o homem é parte dela (FOSTER, 1999, p. 165; LOWY, 2005, p. 21).

\section{Concordando com esta posição, Netto e Braz postulam que:}

Por natureza, entendemos o conjunto do seres que conhecemos no nosso universo, seres que precederam 0 surgimento dos primeiros grupos humanos e continuaram a existir e a se desenvolver depois desse surgimento. Ela se compõe de seres que podem ser agrupados em dos grandes níveis: aqueles que dispõem da propriedade de ser reproduzir (a natureza inorgânica), e aqueles que possuem essa propriedade, os seres vivos, vegetais e animais (a natureza orgânica). A distinção entre os níveis inorgânico e orgânico, contudo, não significa a existência de uma "dupla natureza" de fato, a natureza é uma unidade, articulando seus diferentes níveis numa totalidade complexa (2010, p.35).

Partindo das reflexões iniciais acima, o desenvolvimento do ser social pode ser descrito como processo de humanização dos homens, cujo mesmo se dá através de determinações naturais ${ }^{3}$ que exercem um papel cada vez menor, à medida que pelo trabalho, os homens transformam a natureza e a si mesmos. Segundo Netto e Braz:

O homem, portanto, é a natureza historicamente transformada - mas o que é propriamente humano reside nessa transformação (autotransformação, já que propiciada pelo trabalho realizado pelos homens), que situa o homem para além da natureza e o caracteriza como ser social (2010, p.37).

\footnotetext{
${ }^{3}$ Por determinações naturais, entendemos o processo de afastamento das barreiras naturais está relacionado ao homem e a sua capacidade de transformar a natureza através do trabalho o que o torna cada vez mais um ser que põe cada vez mais elementos e determinações sociais, e cada vez menos é dependente das determinações naturais, sem nunca aboli-la por inteiro. Significa que o homem passa por um processo não somente de alteração da natureza, mais também de alterar as condições sociais e humanas, perpetuando assim esse afastamento natural. No entanto cabe salientar que há uma insuperável relação do homem com a natureza.
}

Revbea, São Paulo, V. 9, N 1:132-156, 2014. 
trabalho surge como a objetivação primária do ser social e suas mediações são cada vez mais complexas, bem como as necessidades e as possibilidades de novas objetivações. Através de seus membros (homens e mulheres), transforma matérias primas em produtos que atendam às suas necessidades, cuja transformação é obtida através da atividade a que denominamos trabalho.

A realização do trabalho só se efetiva num movimento indissociável em dois planos: subjetivo (processado no âmbito do sujeito) e objetivo (resultando na transformação material da natureza), no qual sua efetivação constitui uma objetivação do sujeito que atua. O trabalho revela como se articulam essas duas categorias, pois o ser social tem origem na síntese entre subjetividade $e$ objetividade. Através da atividade prática o que antes se achava na consciência (agora se encontra fora dela), transformado em um objeto. $\mathrm{Na}$ compreensão de Tonet (2013, p.97):

a relação entre esses dois momentos, o que se acha na consciência não é simplesmente produto da sua atividade, mas já é resultado de elementos capturados da própria realidade objetiva. A atividade prática é o meio pelo qual a subjetividade imprime na matéria externa a forma previamente mentada. Por sua vez, a atividade teórica é a mediação através da qual a consciência transforma a realidade objetiva em ideias. Embora consciência e realidade objetiva tenham do ponto de vista ontológico, o mesmo estatuto, não tem a mesma importância do ponto de vista da relação entre esses dois momentos. Não se trata, portanto, de uma simples inter-relação entre dois momentos. Trata-se de uma síntese na qual a objetividade detém o caráter de momento predominante.

Marx em A Ideologia Alemã (2009, p. 43-44) apontava que:

Só agora, depois de termos considerado quatro momentos, quatro facetas das relações históricas primordiais, descobrimos que o homem também tem "consciência". Mas, também logo de início, não como consciência "pura". O "espírito" tem consigo de antemão a maldição de estar "preso" à matéria, a qual nos surge aqui na forma de camadas de ar em movimento, de sons, numa palavra, da linguagem. (...) A consciência é, pois, logo desde o começo, um produto social, e continuará a ser enquanto existirem homens.

Isso, não esconde o fato de que a objetividade é a categoria principal. Essa relação é explicitada por Marx quando afirma (2009, p. 32): "Não é a consciência que determina a vida, é a vida que determina a consciência". Essa afirmação revela sua importância porque permite superar tanto o objetivismo, sob a forma de materialismo mecanicista e/ou economicismo quanto o 
idealismo. O materialismo mecanicista assinala que o homem é produto das circunstâncias, não cabendo à consciência qualquer parte no processo. Já para idealismo, o mundo é produto das nossas ideias, estabelecendo, assim, a base para a forma de voluntarismo.

Diante destas argumentações, Tonet aponta a relevância para o entendimento do ser social (2013, p. 98):

\begin{abstract}
o ser social tem como ponto de partida o trabalho, síntese de teleologia e causalidade e, como tal, ato ontologicamente fundante do ser social. O trabalho, por sua vez, é a mediação através da qual o homem transforma a natureza, adequando-a aos seus fins e, ao mesmo tempo constrói a si mesmo. Da natureza do trabalho também decorre o fato de que o homem é um ser essencialmente interativo, social, universal, consciente e livre. A partir do trabalho e como exigência da complexificação do ser social surgem inúmeras outras dimensões da atividade humana, cada qual com uma função própria na reprodução do ser social. E, enfim, da análise do trabalho decorre, naturalmente, a constatação de que o homem é um ser radicalmente histórico e social.
\end{abstract}

Consequentemente o trabalho constitui o ser social, porém, não significa que o ser social não deva ser reduzido ou esgotado no trabalho. Quanto mais desenvolvido é o ser social, mais as suas objetivações transcendem o espaço relacionado ao trabalho. Ou melhor, no ser social constatamos a existência de esferas de objetivação que se tornaram independentes das exigências imediatas do trabalho: a ciência, a filosofia, a arte etc. Para indicar que o ser social é mais que trabalho, uma vez que, ele cria objetivações, há uma categoria central: a práxis. A práxis envolve o trabalho, que é o seu modelo, contudo, inclui mais que ele e inclui todas as objetivações humanas. Tal categoria permite compreender que a riqueza do ser social verifica-se na e pela práxis. A categoria práxis revela o homem como ser criativo e autoprodutivo, pois o homem é produto e criação da sua atividade.

Porém, em determinadas condições histórico-sociais, os produtos do trabalho humano não se mostram como objetivações que expressam a humanidade dos homens, surgindo como algo que foge ao seu controle, passando a controlá-los como uma força que lhe é superior. Nestas condições, as objetivações, não se revelam aos homens como expressão de sua força, pelo contrário, se voltam contra eles sendo exteriores e transcendentes. Tal inversão determina o fenômeno da alienação: 
A alienação é a própria de sociedades ontem têm a vigência a divisão social do trabalho e a propriedade privadas dos meios de produção fundamentais, sociedades nas quais o produto da atividade do trabalhador não the pertence, nas quais 0 trabalhador é expropriado - quer dizer, sociedades nas quais existem formas determinadas de exploração do homem pelo homem (NETTO; BRAZ, 2010, p.45).

Sendo assim, a alienação adentra o conjunto das relações sociais manifestando-se nas relações instituídas entre seus membros se dirigindo a uma cultura alienada que abarca à todos e tudo, deixando de promover a humanização do homem dos quais exerce regressões do ser social. Isso vem indicar que na sociedade capitalista as mediações se tornam mais complexas, onde o valor atua como mediador das relações humanas e de acesso à natureza (RODRIGUES, 2002, p. 12). Com essa divisão, o trabalho e seus produtos passaram a ser, qualitativa e quantitativamente, distribuídos de forma desigual (MARX E ENGELS, 1996, p. 44-48), como também as relações homem-natureza assumem novos postulados, em que novas perspectivas são assumidas no lucro, exigindo um uso mais acelerado dos recursos naturais extraídos pelo trabalho (RODRIGUES, 2002, p. 12).

No entendimento de Konder,

Marx chamou de alienação do trabalho precisamente esse fenômeno pelo qual o trabalhador, desenvolvendo a sua atividade criadora em condições que the são impostas pela divisão da sociedade em classes, é sacrificado ao produto do trabalho. Para Marx, os regimes baseados na propriedade privada dos meios de produção - sobretudo o capitalismo tendem a transformar o homem num mero meio para a produção da riqueza particular (simbolizada pelo dinheiro). Em lugar do produto, é o produtor que fica subordinado às exigências do produto, às exigências do mercado capitalista onde o produto vai ser vendido (2011, p.35).

Segundo Mészáros,

A alienação da humanidade, no sentido fundamental do termo, significa perda de controle: sua corporificação numa força externa que confronta os indivíduos como um poder hostil e potencialmente destrutivo. Quando Marx analisou a alienação nos seus Manuscritos de 1844, indicou os seus quatro principais aspectos: 1) a alienação dos seres humanos em relação à natureza; 2) à sua própria atividade produtiva; 3) à sua espécie, como espécie humana; e 4) de uns em relação aos outros. Ele afirmou enfaticamente que tudo isso não é uma 
"fatalidade da natureza" - como de fato são representados os antagonismos estruturais do capital, a fim de deixá-los onde estão - mas uma forma de auto-alienação. Dito de outra forma, não é o feito de uma força externa todo-poderosa, natural ou metafísica, mas o resultado de um tipo determinado de desenvolvimento histórico que pode ser positivamente alterado pela intervenção consciente no processo histórico para "transcender a auto-alienação do trabalho" (MÉSZÁROS, 2006, p.14).

Compreendemos que o desenvolvimento do ser social jamais se expressou como igual desenvolvimento de humanização de todos os homens, porque o preço do seu desenvolvimento tem sido marcado por uma humanização desigual. Ou seja, o processo de humanização tem sido realizado à margem do sacrifício da maioria dos homens. Desta forma, numa sociedade que supere a divisão social do trabalho e a propriedade privada dos meios de produção podemos almejar que todas as possibilidades de desenvolvimento do ser social se tornem viáveis a todos os homens. Por outro lado, no seu processo formativo-social, os homens podem tornar-se indivíduos sociais, isto é, homens singulares que se humanizam à base da socialização que lhes torna acessíveis as objetivações já constituídas do ser social. Eles desenvolvem sua personalidade a partir do processo de amadurecimento segundo as condições sociais que lhe são oferecidas, onde cada um se apropria das objetivações existentes na vida social e através delas, reside seu processo de construção da sua subjetividade.

\section{Segundo Netto e Braz,}

A subjetividade de cada homem não se elabora nem a partir do nada, nem num quadro de isolamento: elabora-se a partir das objetivações existentes e no conjunto de interações em que o ser singular se insere. A riqueza subjetiva de cada homem resulta da riqueza das objetivações de que ele pode se apropriar. E é a modalidade peculiar pela qual cada homem se apropria das objetivações sociais que responde pela configuração de sua personalidade (2010, p.47).

Entendemos que qualquer forma de contrapor sociedade $x$ indivíduo acaba falseando a socialização, porque o indivíduo social só pode constituir-se no patamar das relações sociais, sendo que a marca da originalidade de cada indivíduo social não impõe que deve existir desigualdade entre todos. Para que a diferença se constitua; para que todos os sujeitos possam construir a sua personalidade, é necessário que as condições sociais para que se socializem sejam iguais e justas para todos.

O trabalho do homem media sua relação com a natureza, adaptandose às exigências e demandas humanas, contudo, a fonte de riqueza é natureza Revbea, São Paulo, V. 9, N 1:132-156, 2014. 
de onde são extraídos os elementos transformados em produtos (RODRIGUES, 2002). No capítulo décimo quarto do livro I de O Capital, Marx menciona o valor da natureza na produtividade, sendo que alguns elementos dependem das condições naturais e da estrutura social:

a produtividade o trabalho depende das condições naturais. Essas condições podem se referir à própria natureza do homem, como raça etc... ou à natureza que o cerca. As condições naturais externas se distinguem economicamente em duas grandes classes: riquezas naturais, de meios de subistência, isto é, solo fértil, águas piscosas etc., e riquezas naturais de meios de trabalho, a saber, quedas d' águam rios navegáveis, madeira, metais (MARX, 1989, p.588.)

Desde os primeiros tempos da humanidade houve uma divisão do trabalho, que no início se dava em função de características fisiológicas, como gênero, idade, força física, até considerando mútua cooperação entre culturas e exercendo influência nos povos contemporâneos (DURKHEIM, 2005). "Nas sociedades antigas o trabalho se dava de modo coletivo, orgânico, destinado basicamente a produção de bens, visando de maneira objetiva à satisfação das necessidades primárias e o cerne limitava-se à obtenção de valores de uso" (RODRIGUES, 2002, p. 12). Opondo-se as sociedades pré-capitalistas, nas sociedades modernas o acesso ao solo foi regulamentado por relações sociais, jurídicas e políticas mais complexas, onde a terra transformou-se em propriedade privada.

\begin{abstract}
É na sociedade capitalista que as mediações são mais complexas, onde o valor atua como mediador das relações humanas e do acesso ao restante da natureza, biótica e abiótica. Porém este acúmulo de mediações nunca oculta, no pensamento marxiano, o fato de que a natureza constitui a base de toda atividade humana. E uma base diferenciada, tal qual a diversidade de todos os elementos naturais que provoca no trabalho humano rendimentos diferentes e tempos de transporte também diversos, tudo isso refletido nos valores mercantis e a partir dos quais os proprietários das benesses os quais os proprietários das benesses naturais reivindicam uma parte do produto de tal riqueza natural em forma de renda da terra (FOLADORI, 1997, p.1556-156).
\end{abstract}

Igualmente, a relação homem/natureza assume novas perspectivas, bem como objetivos definidos onde o lucro e a valorização do capital são determinados como valores maiores, o qual exige um uso exacerbado dos recursos naturais, derivando o esgotamento dos mesmos. Asseveramos que a crise ambiental tem, a partir do escopo marxista, causas econômicas e políticas 
em torno de um projeto societário que está ancorado num processo produtivo equacionado pela lógica mercantil do capital sob a qual está regulamentada.

A concepção de "sustentabilidade" vista sob ótica do seu tempo (século XIX), foi também elencada por ele. Marx explicita a noção de que a natureza deve ser usada com cuidado para que sirva às gerações futuras:

Do ponto de vista de uma formação econômico-social superior, a propriedade privada do planeta nas mãos de indivíduos isolados parecerá tão absurda como a propriedade privada de um homem nas mãos de outro. Nem sequer toda a sociedade, uma nação, mais ainda, todas as sociedade contemporâneas juntas são proprietárias da Terra. Somente são seus possuidores, seus usufrutuários, e devem melhorá-la, como boni patres familias, para as gerações futuras (MARX, 1981, p.987).

Evidenciamos que segundo sua abordagem, as questões políticas e sociais antecedem aos limites naturais:

a partir da análise de Marx podemos entender que 0 problema social e político é sempre anterior ao das possíveis barreiras físicas. É assim que na sociedade capitalista enormes volumes de alimentos são desperdiçados anualmente quando seus preços não chegam a cobrir os custos de produção; pois na Comunidade Econômica Européia alimentam-se as vacas com o leite em pó que elas próprias haviam produzido anteriormente na forma líquida; nos Estados Unidos destinamse milhões de dólares para que os agricultores não semeiem e, tudo isso, ainda que outros milhões, porém de pessoas, morram de fome. A contradição entre o valor de uso e o valor das mercadorias, que é o ponto de partida da exposição marxiana do capitalismo, é também a origem do entendimento destas contradições (FOLADORI, 1997, p.146),

Atualmente, a discussão sobre a sustentabilidade é marcada por uma aliança entre atores sociais, de inter-relação harmônica não só entre estes, mas entre economia, política e relações ambientais. Assim, os problemas sociais e ambientais são restringidos a problemas técnico-gerenciais. Para um projeto que vise à emancipação e o aprofundamento radical e democrático por meio do controle social do Estado e do fortalecimento de movimentos sociais, isso representa dar maior destaque na gestão pública das questões ambientais como meio para garantir ou, tensionar em favor da universalidade e igualdade de direitos como pressupostos para a sustentabilidade (LOUREIRO, 2012). 
Sustentamos que a opção conceitual pela sustentabilidade deve estar ancorada numa leitura dialética do mundo que contrarie as propostas de "sustentabilidade" que naturalizam as relações sociais sob o marco do capital: falamos de socialismo. Certamente, que é preciso repensá-lo à luz do que há de novo trazido no debate sobre a sustentabilidade no século XXI do que descartá-lo e não debater o que realmente indica superarmos as relações capitalistas (fonte de degradação). Concordamos que as palavras de Harvey tem sentido quando diz: "o capitalismo vai bem, quem vai mal são as pessoas". Sendo assim, no debate contemporâneo sobre a sustentabilidade sob a égide do capitalismo não deve haver espaço para conciliações, harmonias ou o denominado "falso realismo". Desta forma Loureiro (2012, p.65-66) assinala que:

não há compatibilidade possível, apenas minimização de efeitos, sendo necessário afirmar outro projeto em toda sua radicalidade, o que envolve afirmar conceitos que expressem isso de modo o mais claro possível. Mesmo partidos e intelectuais de esquerda defendem, em nome de um falso realismo, que a solução está na humanização e ecologização do capitalismo, priorizando o desenvolvimento das forças produtivas, e particularmente da tecnologia e da ciência. Isso é isolar dimensões da vida social que se definem mutuamente pelas relações estabelecidas. Aprimorar algo não significa superá-lo, podemos recompor ecossistemas, criar mecanismos compensatórios com base na ampliação da oferta de bens e serviços, em legislações rigorosas que sejam cumpridas com a execução de programas sociais compensatórios ou distributivos, mas a natureza da expropriação permanece.

A compreensão marxista salienta que existem determinantes econômicos, sociais e políticos que organizam a interação sociedade-natureza, ou seja, as relações sociais de produção. As contradições sociais e a devastação dos recursos naturais provocam nos movimentos sociais e ecológicos, mobilizações como respostas à crise da situação ambiental vigente na sociedade moderna (ALIER, 1998). O desenvolvimento do capitalismo assenta-se na extração ilimitada e conjunta dos recursos naturais e da exploração da força de trabalho do homem. Na sua análise, preocupou-se mais com a exploração da força de trabalho do que com a degradação da natureza. Por fim, assinalamos que para a concepção marxista, a origem ou agravamento dos problemas ambientais está nas contradições sociais e econômicas do modo de produção do capital, considerando a tecnologia e as relações sociais e políticas como os maiores responsáveis pela situação atual da sociedade capitalista. 


\section{Educação Ambiental Crítico-Transformadora: pressupostos à luz da ontologia do ser social}

Estaríamos concretizando as promessas da modernidade, onde a ciência e a tecnologia nos libertariam das limitações impostas pela natureza? Partindo desta premissa básica, iremos ao filósofo francês René Descartes (1596-1650), sendo um dos principais expositores da revolução científica europeia no século XVIII, onde apontava na sua obra o Discurso do Método que "conhecendo a força e as ações do fogo, da água, do ar, dos astros, dos céus e de todos os outros corpos que nos cercam, distintamente como conhecemos dos diversos misteres, e, assim, tornamo-nos como que senhores e possuidores da natureza" (1989, p. 79). Através do conhecimento científico e da sua prática, afirmava Descartes, os sujeitos dominariam a natureza, se tornando seus donos e outrora e obtendo o direito de usufruir dela a qualquer custo.

$\mathrm{Na}$ História o expansionismo colonial mostrou que o possuidor da natureza deveria ser o homem branco, cristão, europeu e ocidental sendo pertencente à aristocracia ou ascendente burguês que, a partir do seu protagonismo cada vez maior no setor econômico, viesse a ocupar os espaços políticos na sociedade pela força do capital. Após quatrocentos anos das afirmações da filosofia cartesiana, a existência humana está em risco e a infinidade de artifícios que permitiriam gozar os frutos da terra encontra-se limitada a uma pequena parcela da população. Apesar de a tecnologia dinamizar safras cada vez maiores, a fome ainda permanece no mundo, sendo que nem as novas descobertas científicas no campo da biologia e dos tratamentos médicos impedem que novos males aumentem se tornando mais uma ameaça no mundo. Soma-se a este processo, a devastação de florestas, erosões de solos, contaminação de mares, lagoas, rios, águas, poluição do ar e a extinção de espécies raras estão cada vez mais aceleradas. Conclui-se que a permanência do padrão capitalista dependerá, tanto da manutenção das injustiças aliadas às desigualdades sociais quanto da sobre-exploração dos recursos ambientais.

Tal padrão de produção e consumo, social e historicamente construído com base numa relação de dominação por seres humanos e dos seres sobre si mesmos, tem como premissas claras: a desigualdade, a injustiça e a utilização ilimitada dos recursos naturais. Trata-se de um padrão capitalista em que a racionalidade do mercado prevalece sobre as demais e em que a obsolescência planejada de bens industrializados é uma das estratégias do processo de produção e consumo (QUINTAS, 2009). Forma que não respeita os diferentes tempos, seja o da natureza, seja dos povos em sua diversidade cultural. Constitui-se num estilo de vida restrito a poucos sendo decorrente de uma sociedade estrutura com raras ou nenhuma perspectiva de sustentabilidade, mas por outro lado, se avaliada segundo valores éticos, tal ordem social não atende às necessidades fundamentais da maioria da população nem muito menos assegura sua sobrevivência no futuro. 
Assim, concebemos que o estado do ambiente no mundo aponta que a crise ambiental evidencia uma crise maior e mais profunda, tal como assevera Quintas (2009, p.37):

O problema está na ordem social vigente, que para garantir um determinado estilo de vida para uns poucos, tem necessariamente que destruir aceleradamente a base material de sustentação da população e condenar a maioria à pobreza, quando não à indigência. Em outras palavras, é a sociedade que está em crise. Os danos e riscos ambientais decorrem de uma determinada ordem social, que se constituiu, historicamente, e se mantém por meio de relações de dominação seja da natureza por seres humanos, seja de humanos por outros humanos.

Visão preponderante de vários setores da economia mundial e da maioria de governos dos Estados nacionais alude que não existe relação de causa e efeito entre a crise ambiental e a maneira de como está estruturada a sociedade. O problema não estaria na "insustentabilidade" desta sociedade, mas no seu aperfeiçoamento, que deve ser obtido tornando o atual padrão de produção e consumo sustentáveis. Simples medida seria adotar tecnologias e práticas ambientalmente saudáveis para se atingir a ecoeficiência e a produtividade dos recursos. Logo, se aposta no que Sachs denomina de "otimismo epistemológico", da qual creem que soluções técnicas sempre podem ser concebidas para garantir a continuidade do progresso material das sociedades humanas (2002). Neste contexto da crise ambiental que emergem as Conferências Ambientais internacionais numa tentativa dos países membros da Organização das Nações Unidas (ONU) a negociarem uma agenda comum de compromissos para enfrentarem os denominados problemas ambientais globais.

Consequentemente, é neste processo que surge como proposta o "desenvolvimento sustentável", cuja finalidade seria de procurar compatibilizar desenvolvimento econômico com proteção ambiental, compreendido pela Comissão Mundial sobre o Meio Ambiente como "aquele que atende às necessidades do presente sem comprometer a possibilidade de as gerações futuras atenderem as suas próprias necessidades" (CMMAD, 1991, p. 46). Sendo assim, o momento conjuntural não abriu espaço para outras propostas estruturadas fora do marco capitalista, onde soluções vagas e imprecisas foram validadas institucionalmente, diplomaticamente, ideológica e socialmente por parte de organismos internacionais, governos e entidades empresariais na lógica do ambientalismo verde (LAYRARGUES, 1996; TERCEIRO, s/d; COSTA, 2011b). Ao caracterizarmos tal movimento dentro da lógica do capital, podemos levar em conta que: 
Para um sistema cuja existência se funda na dominação (da natureza, de pobres por ricos, da maioria pela minoria), no desrespeito à diferença, na concentração de poder, na acumulação de riquezas por poucos e na ascendência do mercado sobre o Estado e a sociedade civil, pensar a possibilidade de construção de outra ordem social com tais características, mesmo que se mantenha leal ao modo de produção capitalista, seria a negação do credo neoliberal e, portanto, do pensamento único (QUINTAS, 2009, p.40).

A partir deste debate, concluí-se que a crise ambiental pode ser vista sob duas formas antagônicas: a) Uma primeira que assume que é possível reverter a atual situação de crise adotando-se o desenvolvimento sustentável como princípio do processo de desenvolvimento. Ou seja, por meio de ajustes nos processos de funcionamento da sociedade se compatibiliza 0 desenvolvimento com proteção ambiental, sem alterarmos radicalmente sua estrutura; b) $A$ segunda tendência, de viés transformador que assume as raízes da crise ambiental no padrão civilizatório europeu, portador da idéia de progresso imposto pelo ideário colonizador como sinalizou Porto-Gonçalves (2002, p.27):

[...] é a partir do Renascimento, com seu antropocentrismo, que o homem se torna todo-poderoso e passa a se lançar no projeto de dominação da natureza. Para dominar, manipular, submeter, chega-se mesmo a falar em torturar, como fez Francis Bacon. Expulso o sagrado da natureza, esta passa a ser vista como objeto, como recurso. O homem descola-se da natureza e, de fora, passa a dominá-la.[...].Um homem desnaturalizado e uma natureza desumanizada, eis o ponto de partida do pensamento/sentimento/ação do mundo moderno [...]. Latina, apontava que é a partir do mundo, desde um mundo histórico, político, erótico ou simbolicamente determinado, que compreendemos a natureza e interpretamos os entes naturais. Se há uma história do mundo, há também a história da natureza. Ou seja, os gregos compreenderam a fysis como eterna, divina, nascente; os medievais compreenderam a natureza como criada (natura naturata), finita, sem princípio de corrupção; o moderno europeu compreendeu a nature ou Natur como sendo a matéria observável matematicamente (desde Galileu) ou explorável economicamente (desde a revolução industrial). A natureza, juntamente com o trabalho e o capital, é a origem do mítico progresso civilizador. Agora se entende o que se quer indicar quando se diz que a natureza é politicamente interpretada: é hermeneuticamente visualizada desde o centro ou a periferia, desde as diversas classes sociais, desde os 
sistemas políticos, principalmente, como matéria de um modo de produção numa formação social determinada.

Transposta para o plano econômico, tal ideário vem associado à noção de que a sociedade pode crescer elevando sua riqueza material com finalidades em si mesmas, como também causalidades diretas. A esta concepção implica no avanço constante do conhecimento científico e que existe um modelo de sociedade civilizada a ser concretizada seguindo 0 modelo civilizatório europeu. Neste escopo, Loureiro afirma que:

O desenvolvimento seria visto de forma liberal, como: sinônimo de crescimento econômico e produção de mercadorias, e a felicidade e o bem-estar estariam associados ao consumo de massa. - série sucessiva de etapas e serem cumpridas, passando de sociedades tradicionais para modernas e industriais. - desenvolvimento capitalista, enquanto única opção existente (2012, p.59).

Também tal ideário de desenvolvimento pode ser traduzido desta forma:

\begin{abstract}
a ideia de desenvolvimento sintetiza melhor que qualquer outra o projeto civilizatório que, tanto pela via liberal e capitalista, como pela via socialdemocrata e socialista , a Europa Ocidental acreditou poder universalizar-se. Desenvolvimento é o nomesíntese da ideia de dominação da natureza. Afinal, ser desenvolvido é ser urbano, é ser industrializado, enfim, é ser tudo aquilo que nos afaste da natureza e que nos coloque diante de constructos humanos, como a cidade, como a indústria. Assim, a crítica à ideia de desenvolvimento exigia que se imaginasse outras perspectivas que não as liberais ou socialistas ou, pelo menos, que essas se libertassem do desenvolvimentismo que as atravessava (PORTOGONÇALVES, 2006, p.62).
\end{abstract}

Compreendemos que esse foi em síntese, o entendimento do projeto político que dominou o conceito de desenvolvimento, cujo modelo foi pautado como único de organização e de riqueza material. A atividade econômica foi assim, naturalizada e o crescimento é aceito como inevitável e como condição de aprimoramento do modo de produção capitalista. Da mesma forma que indicamos que o conceito de progresso é identificado como um dos motores da burguesia em crescimento, que buscava afirmar sua posição hegemônica do seu projeto societário frente a um modelo de organização arcaico que necessitava ser superado para consolidar o mercado e a propriedade privada (LOUREIRO, 2012). 
Sendo assim, a partir deste contexto que surge a exploração do homem aliada à desigualdade e as injustiças sociais, onde a crise ambiental é apenas uma faceta invisível de uma crise com dimensões ainda mais vastas, a de uma concepção de civilização. Concepção que ao separar o ser humano da natureza fez da mesma, outro ser dominado (PORTO-GONÇALVES, 2002). Na compreensão de Quintas (2009, p. 42):

Não há como se construir uma ordem social sustentável, que seja justa e ambientalmente segura, sem o rompimento com a matriz de racionalidades que produziu a crise. Portanto, uma proposta que é inconciliável com a concepção de Desenvolvimento Sustentável e está além do paradigma do caminho do meio. Para esta perspectiva há que se reinventar o mundo para torná-lo sustentável.

Sob o mesmo ponto de vista, Porto-Gonçalves (2006, p.458) assevera que:

tudo nos concita a buscar outra relação da sociedade com a natureza, onde a injustiça social e a sustentabilidade ecológica se façam por meio da liberdade, onde todos tenham direitos iguais para afirmarem sua diferença. Que a diversidade biológica e a cultural na igualdade e na diferença, sejam vistas como os maiores patrimônios da humanidade.

Portanto, buscar uma sociedade justa, democrática e sustentável construída sob a pluralidade social e cultural torna-se uma construção, sobretudo, política! Pois não podemos perder de vista que reformas sociais ou a sua transformação no plano prático são processos. Postulamos que frente ao viés transformador, tais práticas são necessárias, mas não são suficientes, uma vez que, a distinção destas práticas, se dará na finalidade das nossas atuações e intervenções nesta sociedade. Finalidades maiores ancoradas numa justiça ambiental que seja uma prerrogativa desta construção eminentemente política e transformadora.

Postulamos que a adjetivação em voga citada, denominada "transformadora" (LOUREIRO, 2004; 2006a), implica na condição de uma formulação colocada no campo libertário ${ }^{4}$ da educação ambiental. Formulação

\footnotetext{
${ }^{4}$ Para o conceito libertário do qual usamos, tomamos como horizonte teórico a categoria do filósofo Enrique Dussel em sua obra Método para uma Filosofia da Libertação. Para Dussel, a libertação se apresenta com dois propósitos que se fundem em um único: Libertar filosófico-politicamente. Ou seja, quer libertar a filosofia da hegemonia eurocêntrica que se perpetua em nosso meio, mesmo com a incompatibilidade de não verificarmos sua validação na sociedade, por termos valores, crenças, culturas... distintos àquelas em que foram elaboradas, fazendo assim que filosofia seja sinônimo de viagem, abstração, fuga da realidade, etc... E quer libertar-nos politicamente, mostrandonos alguns mecanismos de dominação e exploração que normalmente nos passam desapercebidos no cotidiano e são tão eficazes em seus propósitos, em todas as dimensões de nossa vida. A libertação filosófica e a libertação política se completam e são inseparáveis, contemplam todas as dimensões de nossa vida pessoal e social, sendo assim, possibilitam-nos instrumentos teórico-práxicos para libertação integral, não só como pessoas, mas como sociedade, impelindo-nos a uma nova ordem.
}

Revbea, São Paulo, V. 9, N 1:132-156, 2014. 
à qual se inscrevem os vários exames dados ao termo transformador (libertário, crítico, popular, emancipatório). Tais formulações têm o privilégio de estimular o diálogo fecundo, ora visto por embates teóricos entre pesquisadores ao promover o questionamento às demais abordagens comportamentalistas, reducionistas, dualistas na compreensão da relação sociedade-natureza. No campo em que a Educação Ambiental Transformada existe, há objetivos comuns como também características conceituais, além de enfatizar temáticas relevantes em seu bojo que não devem ser esquecidas. Seja no conceito de sujeito, seja na gestão participativa e popular, seja na dimensão pragmática da educação e seu mito transformador da sociedade. Partimos da premissa que a educação ambiental é uma perspectiva que se instaura e se dinamiza na própria educação, formada através de relações estabelecidas entre as várias tendências educacionais e do próprio ambientalismo, e que tem no debate sobre o "ambiente" e da "natureza", destacadas dimensões relegadas para uma compreensão da vida e da natureza a partir das contradições do projeto societário capitalista.

Já assinalamos que a questão ambiental é complexa, inter e transdisciplinar. Não obstante nada pode ser definido em si, mas em relação em contextos, no tocante ao método da EA Transformadora, é a tradição dialética que melhor busca o entrelaçamento do ambiente e que se propõe a refletir e agir em processos integrados e conexos. Desta forma, a dialética materialista é o exercício totalizador que permite apreendermos a síntese das múltiplas determinações que comportam a unidade. A maneira de pensarmos dialogicamente considera que qualquer parte pode estar em contradição ou ser complementar. Ela permite entendermos a unidade na diversidade, a superação do contraditório pela síntese que estabelece outras contradições num movimento contínuo de transformação.

Enquanto princípio metodológico, a dialética não significa um exame de tudo num único processo, visto que a realidade não é algo estanque (se constituindo num princípio totalitário a crença de que o todo é igual, estático e absoluto). Constitui compreendermos que o singular alcança sentido em suas relações em que o todo é mais que a simples somatória de singularidades, num movimento de mútua constituição. Sendo assim, a dialética é um método que torna possível o diálogo crítico com outras abordagens no campo ambiental que se acumulam de pressupostos comuns na elaboração de suas compreensões de mundo. Citamos a teoria da complexidade, que utiliza no método dialético e para duas grandes formulações que estão inseridas no campo holístico, não dialético (teoria dos sistemas e cibernética) e para a hermenêutica. Através do debate é possível ampliarmos novas perspectivas conceituais e metodológicas sem cairmos em reducionismos comuns próprios do campo.

Contudo, podemos assinalar algumas premissas que garantem a unidade conceitual no campo da EA transformadora tendo em conta o método dialético (LOUREIRO, 2004, p.72): 
- a realidade é a síntese entre sujeito e objeto e não algo externo cuja dinâmica é independente de nossa inserção nesta; - a verdade se explicita na aplicação prática da teoria e na capacidade de atuarmos reflexivamente em sociedade;

- a transformação das condições materiais é a norma para a transformação subjetiva - uma sem a outra significa mudanças pontuais e não revoluções substantivas;

- o sentido da construção do conhecimento e da atuação no mundo é propiciar a emancipação humana e a superação das formas de dissociação sociedade/natureza.

A adjetivação transformadora assevera que o fim da EA é revolucionar os sujeitos em suas subjetividades e práticas nas estruturas existentes. Sinaliza atuar de maneira crítica na superação das relações sociais vigentes, comportando uma ética ecológica que visa efetivar um patamar societário que seja a expressão da cisão com os padrões excludentes que caracterizam o modo de (re) produção do capital. Privilegiar somente um dos aspectos que comportam a espécie humana (seja ético, político, comportamental, sensível, econômico), buscando cindir o social do ecológico é reduzir à uma visão pouco complexa (LOUREIRO, 2004). Frente o desafio de articular o específico e o complexo na EA, Loureiro (2004, p.73) assinala que:

para fins de delimitação da ação e estratégias no planejamento, fazemos recortes e escolhas. Isso é correto e necessário para não se gerar o imobilismo diante do desafio posto, mas o que não se pode fazer é pensar no recorte em si, desconsiderando o contexto, as opções feitas, as condicionantes e o que se pretende alcançar com a prática cotidiana. Desarticular a atuação na realidade local do contexto societário e natural global favorece a fragmentação do conhecimento e o resultado pragmático visto como um fim, com desdobramentos na "esfera pública" muitas vezes contrários ao que se pretendia. Este é o problema de uma vinculação nãodialética entre economia, política e ética. Agir e pensar em um locus pressupõe agir e pensar no todo.

Podemos "educar" para novos padrões de consumo, desde que, se ligamos a um novo modo de produção, oposto ao pretendido pelo capital. Assim, na EA devemos ter clareza que uma atuação crítica sugere que busquemos conhecer a totalidade das relações pela qual se determina nossos padrões societários. Se educar é uma ação, uma necessidade vital de nossa existência, devemos assim ter uma compreensão do seu sentido e finalidade. Mediação que perpassa por processos sociais traduzidos numa dimensão pessoal, reflexiva, objetiva e dialética na realidade. Ou seja, entendida através de múltiplas mediações sociais e ecológicas manifestadas nas esferas individuais e coletivas. "A educação se concretiza pela ação em pensamento e Revbea, São Paulo, V. 9, N 1:132-156, 2014. 
prática, pela práxis, em interação com o outro no mundo. Trata-se de uma dinâmica que envolve a produção e reprodução das relações sociais, reflexão e posicionamento ético na significação política" (LOUREIRO, 2004, p.77).

Fundamentalmente é entender a educação em sua finalidade para avançarmos pela crítica consciente nas estruturas vigentes, pois falar em educação pode se tornar uma fala vazia de sentido prático se permanecer desconexa de uma compreensão das condições efetivas ao processo educativo na sociedade capitalista. A EA Transformadora procura a realização de nossa espécie em sociedade enquanto forma de nos organizarmos coletivamente e não por um descolamento do movimento social. Desse modo,

todo e parte, dialeticamente são um movimento dinâmico, contraditório e complementar, mutuamente constituídos. Do contrário, ou recai-se no holismo generalista, no reio das formas e idéias sem a concretude da vida, no inespecífico, no globalismo desconexo da localidade (quando o todo "domina as partes"); ou na fragmentação, no isolamento de partes, na coisa em si sem fluxos e processos (quando a parte "domina" ou ignora o todo) (LOUREIRO, 2004, p.78).

Em Gramsci encontramos uma contribuição relevante, pois foi autor que levou às últimas consequências o sentido de práxis, enquanto "atividade concreta pela qual o sujeito se afirma no mundo, modificando a realidade objetiva e sendo modificado, não de modo espontâneo, mecânico e repetitivo, mas reflexivo pelo autoquestionamento, remetendo a teoria à prática" (LOUREIRO, 2006a, p. 130). Isso implica o vínculo entre pensamento e prática levando em consideração as relações com o mundo, com o outro, com a história, a intersubjetividade, a reflexão e a ação transformadora da realidade. Segundo Lukács (2003), a práxis é o fazer com que não só o pensamento se aproxime da realidade, mas a realidade se aproxime do pensamento, tornando uma nova realidade. Tanto Gramsci como Lukács forneceram contribuições à reflexão dando efetividade às esferas cultural, política e ideológica nos projetos societários de transformação. Movimento de aprendizado e ação pelo qual saímos do senso comum estabelecido (consciência superficial do real), para a consciência crítica (conhecimento que serve à transformação) da totalidade social (LOUREIRO, 2007a).

Convidando o educador brasileiro Paulo Freire (1993, p.67) ao debate, no seu entendimento práxis "implica a ação e a reflexão dos homens sobre o mundo para transformá-lo". Isso implica à ação intersubjetiva entre sujeitos, sendo uma atividade relativa à liberdade e às escolhas conscientes, feitas pela interação dialógica e pelas mediações que estabelecemos com o outro, com a sociedade e o mundo. É um conceito central para a educação ambiental, pois, conhecer, agir e se perceber no ambiente, deixa de ser um ato teórico-cognitivo e torna-se processual, à qual tornam complexos e concretos na práxis (LOUREIRO, 2006a). 
Para a concepção de Chauí:

A relação entre a teoria e a prática é uma relação simultânea e recíproca por meio da qual a teoria nega a prática enquanto prática imediata, isto é, nega a prática como um fato dado para revelá-lo em suas mediações e como práxis social, ou seja, como atividade socialmente produzida e produtora da existência social. A teoria nega a prática como comportamento e ação dados, mostrando que se trata de processos históricos determinados pela ação dos homens que, depois, passam a determinar suas ações. Revela o modo pelo qual os homens criam suas condições de vida e são, depois, submetidos por essas próprias condições. A prática, por sua vez, nega a teoria como um saber separado e autônomo, como puro movimento de idéias se produzindo uma às outras na cabeça dos teóricos. Nega a teoria como um saber acabado que guiaria e comandaria de fora a ação dos homens. E negando a teoria enquanto saber separado do real que pretende governar esse real, a prática faz com que a teoria se descubra como conhecimento das condições reais da prática existente, de sua alienação e de sua transformação (1980, p.81-81).

Em sua dimensão revolucionária, a práxis é uma prática que aspira transformar radicalmente uma sociedade. Possui um caráter vindouro porque "trabalha" em favor de um melhor porvir humano. Uma práxis revolucionária é aquela que aspira uma ética social de viver bem com e para os outros em instituições mais justas. Supõe transformar as circunstâncias sociais e do próprio ser humano, onde os mesmos são condicionados por uma situação social injusta que se encontram. Este ser-estar em uma situação provoca reações mais ou menos revolucionárias ou, ao contrário, adaptadas a um statu quo (PALÁZON MAYORAL, 2007).

Podemos dizer que:

A humanidade em seus atos e produtos vai deixando pegadas, que revelam a historicidade de seus pensamentos e desejos, de suas necessidades, de suas ambições e ideais que têm humanizado o entorno e vão humanizando as pessoas: a consciência não só se projeta em sua obra, mas também se sabe projetada além de suas próprias expectativas. A práxis é, pois, subjetiva e coletiva; revela conhecimentos teóricos e práticos (supera unilateridades). Além do mais, e isto é básico, o trabalho de cada ser humano entra nas relações de produção relativas a um âmbito sócio-histórico (PALÁZON MAYORAL, 2007, p.4). 
Em síntese, precisamos superar as formas de expropriação que incitam a dicotomia sociedade-natureza, por consequência, a EA não se refere somente as relações ecológicas ou biológicas como se as sociais negassem ambas, embora todas as relações que nos situam no planeta ocorrem em e na sociedade. Educar ambientalmente pode ser visto pela unicidade dos processos que problematizam os atributos da vida, repensando valores e comportamentos, com os que atuam na dinâmica social, política, econômica, cultural, quer orientando horizontes sustentáveis de modo assinalarmos padrões societários mais igualitários.

\section{REFERÊNCIAS}

ALIER, J.M. Da economia ecológica ao ecologismo popular. Blumenau: FURB, 1998.

ALTVATER. E. Existe um marxismo ecológico? In: BORON, A; AMADEO; J; GONZÁLES, S. A Teoria marxista hoje. Buenos Aires: CLACSO, 2006. p. 327-349.

COSTA, C.A. Marketing ecológico: uma reflexão sobre as relações perversas do "ambientalismo verde" na sociedade capitalista. Pelotas, $2011 \mathrm{~b}$.

COSTA, C.A.; VERAS NETO, F.Q.; LOUREIRO, C.F. Trabalho, materialismo e natureza segundo Marx e Engels. Contribuciones a la Economía, Málaga (Espanha), fevereiro de 2011a. Disponível em: http://www.eumed.net/ce/2011a/ Acesso em 20/03/2014.

COGGIOLA, O. Crise ecológica, biotecnologia e imperialismo. s/d.

COGGIOLA, O. O Capital contra a história: gênese e estrutura da crise contemporânea. São Paulo: Xamã Edições Pulsar, 2002.

CHASIN, J.M. Estatuto ontológico e resolução metodológica. In: TEIXEIRA, F.J.S. Pensando com Marx: uma leitura crítico-comentada de O Capital. São Paulo, Ensaio, 1995.

CHAUÍ, M. O que é ideologia. 38. ed. São Paulo: Brasiliense, 1980.

CMMAD. Nosso futuro comum. 2ed. Rio de janeiro: FGV, 1991.

DESCARTES, R. Discurso do Método. Brasilía: UNB; São Paulo: Ática, 1989.

DUSSEL, E. Filosofia da Libertação na América Latina. 2 ed. São Paulo: Loyola, 1980.

FOLADORI, G. Os limites do desenvolvimento sustentável. Campinas: Unicamp, 2001.

FOLADORI, G. A Questão ambiental em Marx. In: Crítica marxista. n, 4, São Paulo: Xamã, 1997, p. 140-161.

FOSTER, B. A Ecologia de Marx. Rio de Janeiro: Civilização Brasileira, 2005. 
FOSTER, B. Marx e o meio ambiente. In: WOOD, E; FOSTER, J. B. (Orgs.). Em defesa da história: marxismo e pós-modernidade. Rio de janeiro: Zahar, 1999. p. 161-74.

FREIRE, P. Pedagogia do Oprimido. 22 ed. São Paulo: Paz e Terra, 1993.

FRIGOTTO, G. O enfoque da dialética materialista histórica na pesquisa educacional. In: FAZENDA, I (Org). Metodologia da pesquisa educacional. São Paulo: Cortez, 1989. p. 69-90.

GADOTTI, M. Concepção dialética da educação. São Paulo: Cortez, 1983.

HARVEY, D. Justice, nature and the geography of difference. USA: Blackwell Publishers, 1996.

KONDER, L. Marx: vida e obra. 7 ed. Rio de Janeiro: Paz e Terra, 2011.

LAYRARGUES, P. Educação ambiental e ambientalismo empresarial: um caso ideológico. In: MATA, S.F.;LOUREIRO, C.F.B. (Orgs.). Educação ambiental e a nova ordem mundial. Rio de Janeiro: UFRJ. 1996. p. 36-43.

LOUREIRO, C.F.B. Trajetória e fundamentos da Educação Ambiental. São Paulo: Cortez, 2006a.

LOUREIRO, C.F.B. Educação Ambiental Transformadora. In: LAYRARGUES, Philippe Pomier (coord). Identidades da educação ambiental brasileira / Ministério do Meio Ambiente. Diretoria de Educação Ambiental; Ministério do Meio Ambiente, 2004. p. 65-82.

LOUREIRO, C.F.B. Complexidade e Dialética: contribuições a práxis política e emancipatória em educação ambiental. Campinas, Educação e Sociedade, vol. 27, n. 94, p. 131-152, jan./abr. 2006b.

LOUREIRO, C.F.B. Educação Ambiental e "Teorias críticas". In: GUIMARÃES, M. (Org.). Caminhos da Educação Ambiental: da forma à ação. São Paulo: Papirus, 2006c. p. 51-86.

LOUREIRO, C.F.B. O Movimento ambientalista e o pensamento crítico. Rio de Janeiro: Quartet, $2006 f$.

LOUREIRO, C.F.B. A Educação Ambiental no Brasil: Proposta pedagógica. In: Educação Ambiental no Brasil. Ano XVIII, boletim 01, Secretaria de Educação a Distância. MEC, Março de 2008. p. 13-20.

LOUREIRO, C.F.B. Sustentabilidade e educação: o olhar da ecologia política. São Paulo: Cortez, 2012.

LOWY, M. Progresso destrutivo: Marx, Engels e a Ecologia. In: LOWY, M. Ecologia e Socialismo. São Paulo: Cortez, 2005. p. 19-40.

LUKÁCS, G. História e consciência de classe: estudos sobre a dialética marxista. São Paulo: Martins Fontes, 2003.

LUKÁCS, G. Ontologia do Ser Social: os princípios ontológicos fundamentais de Marx. São Paulo: Editora Ciências Humanas, 1979. 
MARX, K. A ideologia alemã. São Paulo, Expressão Popular, 2009.

MARX, K. Manuscritos Econômicos-filosóficos. Edições 70, 1993.

MARX, K. El Capital. Tomo I, v. II. México: D.F, 1979.

MARX, K. El Capital. Tomo III, v. I. México: Siglo XX, 1981.

MARX, K. O Capital: crítica da economia política. Livro I, v. II. Rio de Janeiro: Bertrand Brasil, 1989.

MARX, K. O Capital: crítica da economia política. São Paulo: Nova Cultural, 1985, v. I, t. 1.

MARX, K. O Capital. Rio de Janeiro, Civilização Brasileira, 1975.

MARX, K. Para a crítica da economia política: Salário, preço e lucro: O rendimento e suas fontes; a economia vulgar. In: Os economistas. São Paulo: Abril Cultural, 1982.

MARX, K. Posfácio à 2 edição 1983. In: MARX, K. O Capital. São Paulo: Abril Cultural, 1983.

MARX, K. Contribuições à Crítica da Economia Política. 2. ed. São Paulo: Martins Fontes, 1983.

MARX, K.; ENGELS, F. A Ideologia alemã. São Paulo: Grijalbo, 1977.

MÉSZÁROS, I. A teoria da alienação em Marx. São Paulo: Boitempo, 2006.

MÉSZÁROS, I. O Poder da ideologia. São Paulo: Boitempo, 2004.

MÉSZÁROS, I. A educação para além do capital. São Paulo: Boitempo, 2005.

NETTO, J.P; BRAZ, M. Economia Política: uma introdução crítica. 6 ed. São Paulo: Cortez, 2010.

NETTO, J.P. Capitalismo e Reificação. São Paulo: Ed. Ciências Humanas, 1993.

NETTO, J.P. Introdução ao estudo do método de Marx. São Paulo: Expressão Popular, 2011.

PALAZÓN MAYORAL, M.R. A filosofia da práxis segundo Adolfo Sánchez Vázquez. In: BORON, A.; AMADEO, J.; GONZALES, S. (Orgs). A Teoria marxista hoje: Problemas e perspectivas. Buenos Aires: CLACSO, 2007. p. 113.

em:

http://bibliotecavirtual.clacso.org.ar/ar/libros/campus/marxispt/cap.13.doc

Acesso em: 22/08/1012.

PORTO-GONÇALVES, C.W. A globalização da natureza e a natureza da globalização. Rio de Janeiro: Civilização Brasileira, 2006.

PORTO-GONCALVES, C.W. Natureza e sociedade: elementos para uma ética da sustentabilidade. In: QUINTAS, J.S. (Org.). Pensando e praticando a educação ambiental na gestão do meio ambiente. Brasília: Ibama, 2002.

revista brasileira educação ambiental 
PORTO-GONÇALVES, C.W. Os (des)caminhos do meio ambiente. 2 ed. São Paulo: Contexto, 1990.

QUINTAS, J.S. Educação no processo de gestão ambiental pública: a construção do ato pedagógico. In: LOUREIRO, C.F.B; LAYRARGUES, P (Orgs.). Repensar a educação ambiental: um olhar crítico. São Paulo: Cortez, 2009. p. 33-77.

RODRIGUES, F.X. Estudo do meio ambiente e a tradição marxista. In: Santa Cruz, Barbarói, n. 17, jul-dez, 2002, p. 7-21.

SACHS, I. Caminhos para o desenvolvimento sustentável. Rio de Janeiro: Garamond, 2002.

SANCHEZ GAMBOA, S. A Dialética na pesquisa em educação: elementos de contexto. In: FAZENDA, I. (Org.). Metodologia da pesquisa educacional. São Paulo: Cortez, 1989. p. 92-115.

SANFELICE, J.L. Dialética e Pesquisa em Educação. In: LOMBARDI, J.; SAVIANI, D. (Orgs.). Marxismo e Educação. Campinas: Autores Associados: 2005. p. 69-94.

SEVERINO, A. O uno e o múltiplo: o sentido antropológico do interdisciplinar. In: JANTSH, A.; BIANCHETTI, L. (Orgs.). Interdisciplinaridade: para além da filosofia do sujeito. Petrópolis: Vozes, 2004. p. 159-175.

TERCEIRO, E. Crise ambiental e produção destrutiva: apontamentos sobre a insustentabilidade do eco-desenvolvimento capitalista. Dossiê marxismo e ecologia. s/d.

TONET, I. Método científico: uma abordagem ontológica. São Paulo: Instituto Lukács, 2013. 